\title{
Meningkatkan Keterampilan Menggunakan Program Jaws Melalui Tutor Sebaya Bagi Anak Tunanetra
}

\author{
Riska Nadia Utami', Yarmis Hasan', Safaruddin ${ }^{3}$ \\ ${ }^{12}$ Universitas Negeri Padang, Indonesia \\ Email: riskautami155@yahoo.co.id
}

\section{Kata kunci:}

Tunanetra, jaws, tutor sebaya

\begin{abstract}
This research is motivated by the presence of class IX blind students at SLB Wacana Asih Padang who have not mastered how to use a good jaws program. Students have difficulty using shortcuts that make it easier to use the jaws program. This study uses a type of classroom action research conducted in the form of collaboration with the classroom teacher, as the subject of the research, namely one blind child class IX. The researcher acts as the giver of action, while the teacher as the observer. In this study the data obtained through observation, and test actions and then analyzed qualitatively and quantitatively. The results of learning using class IX blind children's jaws through peer tutoring have increased, after being given FF learning outcomes actions have increased there is a cycle I $65 \%$ and cycle II $95 \%$. From the research data it can be concluded that peer tutors can improve their skills using the jaws program for blind children of class IX at the SLB Wacana Asih Padang.
\end{abstract}

(7) (2) This is an open access article distributed under the Creative Commons 4.0 Attribution License, This license lets others remix, tweak, and build upon your work even for commercial purposes, as long as they credit you and license their new creations under the identical terms $(2018$ by author and Universitas Negeri Padang.

\section{Pendahuluan}

Teknologi dan informasi merupakan kebutuhan hidup yang harus dikuasai oleh manusia salah satunya komputer. Karena komputer merupakan sarana dan prasarana yang memudahkan manusia untuk mengakses informasi dan menambah wawasan, selain itu komputer terutama laptop mudah dibawa kemana-mana dan efisien dalam penggunaannya. Tunanetra terjadi karena rusaknya organ anatomi mata yang menyebabkan terganggunya fungsi penglihatan ketunanetraan menyangkut struktur anatomi dan fungsi organ mata (Hadi, 2005).

Anak tunanetra adalah individu yang mengalami hambatan pada penglihatanya, meskipun anak tunanetra mengalami hambatan pada penglihatanya bukanlah halangan baginya untuk mempelajari teknologi. Hal ini dilandasi oleh Penelitian (Baharudin, 2006) yang menyebutkan bahwa keterbatasan fisik bukan hambatan dalam mempelajari komputer dengan hadirnya screen reader yang bisa mengubah tampilan Visual menjadi audio tunanetra bisa mengerjakan pekerjaannya sehari-hari. Bahkan mereka juga bisa menjelajah dunia melalui internet. Sekarang banyak tersedia beberapa software komputer untuk tunanetra dengan memanfaatkan software inilah mereka bisa menggunakan komputer.

Komputer yang digunakan tentu harus mempunyai program yang bisa mengubah tampilan visual menjadi audio, salah satu program yang dapat digunakan untuk anak tunanetra adalah jaws. Menurut hasil penelitian (Safaruddin, Yunus, \& Efrina, 2013) menunjukkan bahwa program jaws efektif untuk meningkatkan kemampuan mengetik pada klien tunanetra walaupun klien tunanetra mengalami hambatan dalam penglihatannya, menyebabkan kesulitan dalam melihat dan berpindah tempat tetapi pembelajarannya masih bisa dioptimalkan salah satunya dengan meningkatkan 
kemampuan mengetik menggunakan jaws. Dengan menggunakan jaws memungkinkan seorang tunanetra untuk menggunakan komputer serta dapat digunakan dalam pembelajaran komputer.

Pembelajaran komputer termasuk dalam pembelajaran teknologi informasi dan komunikasi, sekolah yang mempunyai komputer akan mengajarkan siswa-siswinya, salah satunya anak tunanetra untuk belajar komputer baik itu anak tunanetra total maupun dengan anak low vision guna untuk meningkatkan kemampuan anak dalam mengikuti perkembangan zaman, agar tidak bergantung tentang informasi kepada orang awas dan guna sebagai sumber belajar siswa guna untuk mengikuti perkembangan informasi.

Berdasarkan pengamatan penulis anak tunanetra kurang disertakan dalam kegiatan pengoperasian komputer padahal sudah ada program jaws yang berguna untuk membantu anak . tetapi program jaws yang ada dikomputer sekolah hanya aktif selama 40 menit, setelah 40 menit maka program jaws tadi akan berhenti beroperasi. Dalam penggunaan jaws yang telah ia pelajari sebelumnya oleh anak tunanerta disekolah, menggunakan jaws 40 menit hasil kemampuan awal anak hanya bisa mengetikkan nama nya saja. Sedangkan anak masih dibantu guru kelas dalam membuka lembar kerja microsoft word untuk mengetik. Mengetik selain namanya sendiri, menyimpan dokumen belum bisa serta belum paham tentang penggunaan shortcut yang membantu dalam pengoperasian jaws.

Metode yang digunakan guru adalah metode ceramah dan metode langsung. Guru menjelaskan tentang cara menggunakan laptop kepada anak menggunakan jaws 40 menit setelah itu guru melepas anak untuk bekerja sendiri. Kurangnya pengawasan yang dilakukan guru menyebabkan anak kesulitan dalam menggunakan laptop. Sehingga anak masih belum memahami cara menggunakan program jaws

Berdasarkan permasalahan yang ditemukan penulis bersama-sama dengan guru ingin meningkatkan keterampilan penggunaan jaws. Program jaws yang akan digunakan diinstal pada laptop dan dalam penggunaannya menggunakan microsoft word. Metode pembelajaran yang penulis gunakan adalah metode tutor sebaya. . Menurut hasil penelitian (Arjanggi, 2010) menyebutkan tutor teman sebaya efektif untuk meningkatkan hasil belajar, berdasarkan hasil penelitian tersebut tutor sebaya dirasa efektif untuk meningkatkan kemampuan anak tunanetra dalam pengoperasian komputer terutama laptop.

Pembelajaran komputer terutama laptop yang dilakukan oleh tunanetra sering bertanya kepada temannya yang low vision untuk membantu ia dalam mempelajari komputer seperti letak tombol dan letak pengaturan. Hal ini dapat membantu anak tunanetra dalam meningkatkan kemampuannya dalam mempelajari komputer terutama laptop. Untuk itu peneliti berdiskusi bersama guru kelas yang nantinya akan dijadikan kolaborator, dimana peneliti nantinya akan melakukan tindakan kelas bagi siswa tunanetra kelas IX A. Dalam meningkatkan keterampilan menggunakan program jaws melalui tutor sebaya.

Tutor sebaya yaitu memanfaatkan kemampuan siswa yang berprestasi serta memiliki hubungan sosial yang tinggi untuk memberikan bimbingan yang berupa arahan, petunjuk, dan motivasi kepada temannya yang berada dibawah kemampuannya atau kurang berpestasi (Rijalullah, 2003). Siswa yang dibantu dapat mengatasi kesulitan belajar atas ketidakpahamannya terhadap materi pelajaran yang di pelajari. Bimbingan yang diberikan oleh seorang tutor adalah teman sekelas atau teman sebangku yang usianya relatif sama, siswa yang kurang paham secara leluasa bisa bertanya langsung kepada teman sebangkunya sehingga suasana belajar menjadi menyenangkan karna adanya interaksi belajar yang aktif.

\section{Metode}

Penelitian tindakan kelas adalah suatu kegiatan proses belajar mengajar dalam penelitian ilmiah yang dilakukan secara rasional, sistematis dan empiris reflektif terhadap berbagai tindakan yang dilakukan oleh guru atau dosen (tenaga pendidik), kolaborasi (tim peneliti) yang sekaligus sebagai 
peneliti, sejak disusunnya suatu perencanaan sampai penilaian terhadap tindakan nyata di dalam kelas yang berupa kegiatan belajar-mengajar, untuk memperbaiki dan meningkatkan kondisi pembelajaran yang dilakukan (Iskandar, 2011).

Penelitian ini peneliti lakukan dengan berkolaborasi dengan guru kelas, disini peneliti bertindak sebagai pemberi tindakan dan guru kelas sebagai pengamat. Adapun dalam hal merumuskan rencana pelaksanaan pembelajaran serta menentukan langkah-langkah menggunakan program jaws peneliti lakukan dengan berdiskusi bersama-sama dengan guru kelas. Subjek dari penelitian ini adalah satu orang siswa tunanetra dengan inisial FF.

Penelitian tindakan kelas dilaksanakan 4 tahap, yaitu :merencanakan, melakukan tindakan, mengamati dan refleksi. desain PTK berbentuk siklus- siklus. Satu siklus terdiri atas empat fase, yaitu 1) fase perencanaan (planning), 2) fase pelaksanaan (action), 3) fase observasi/pemantauan (observations), dan fase refleksi (reflection) (Muhadi, 2011) Penelitian ini terdiri dari 2 siklus, dimana setiap siklus terdiri atas 4 kali pertemuan.

\section{Hasil Penelitian Dan Pembahasan}

Kondisi awal merupakan kemampuan yang telah diperoleh sebelumnya oleh anak. Kemampuan awal menunjukkan pemahaman siswa terhadap suatu materi pelajaran. Dapat disimpulkan kondisi awal atau kemampuan awal merupakan kemampuan anak sebelum diberikan tindakan atau perlakuan.

Berdasarkan hasil analisis data dapat dilihat bahwa tutor sebaya dapat meningkatkan keterampilan menggunakan program jaws bagi anak tunanetra. Aspek yang sudah dikuasai oleh anak ada 5 aspek diantaranya adalah aspek mempraktekkan cara menggunakan Jaws dalam membaca dokumen perhuruf, mempraktekkan cara menggunakan Jaws dalam membaca dokumen perkalimat, menghapus tulisan, memindahkan baris baru, Memberi spasi.

Sementara aspek yang belum dikuasai anak ada 15 aspek diantaranya membuka lembar kerja baru, membuka file, menyimpan dokumen, membuka lembar kerja microsoft word, menebalkan huruf, memiringkan huruf, menggaris bawah huruf, membuat tulisan ditengah,mengganti ukuran huruf, mengcopy tulisan, mempastekan tulisan, keluar dari lembar kerja microsoft word, mempraktekkan cara menggunakan jaws dalam membaca dokumen perkata, mempraktekkan cara menggunakan jaws dalam membaca dokumen perparagraf dan yang terakhir memperbesar tulisan. Aspek yang sudah dikuasai anak Untuk hasil kemampuan awal siswa FF masih belum maksimal dan terbilang rendah siswa FF memperoleh skor sebesar $25 \%$.

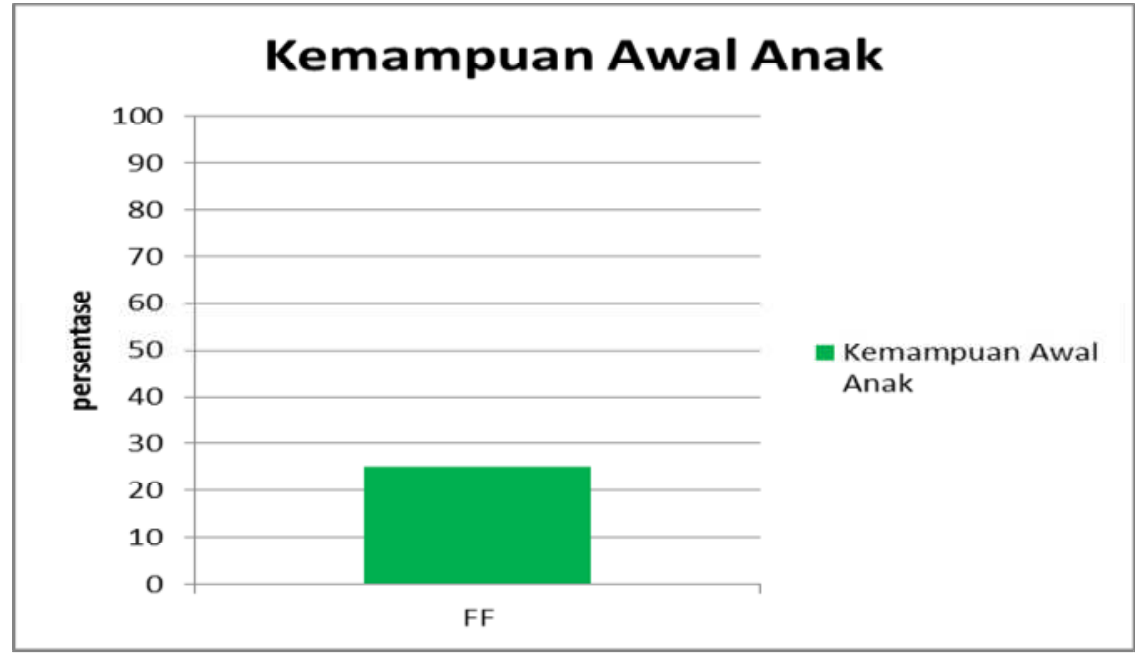

Grafik 1. Kemampuan Awal Siswa Menggunakan Program Jaws 
Berdasarkan grafik diatas dapat disimpulkan bahwa kemampuan awal siswa tunanetra dalam mengunakan program jaws masih rendah dan belum maksimal, oleh karena itu peneliti ingin mencoba menerapkan tutor sebaya dalam meningkatkan kemampuan siswa dalam menggunakan program jaws. Sebelum masuk ke siklus I peneliti bersama kolaborator merancang diantaranya melakukan analisis kurikulum teknologi informasi dan komunikasi untuk menemuan kompetensi inti dan kompetensi dasar serta merumuskan indikator yang sesuai, membuat rancangan rencana pelaksanaan pembelajaran keterampilan menggunakan program jaws melalui tutor sebaya bagi anak tunanetra, membuat format observasi untuk melihat proses pelaksanaan kegiatan belajar mengajar, membuat instrumen yang digunakan dalam siklus penelitian tindakan kelas, menyusun alat evaluasi.

Selanjutnya dilakukan tindakan, Hasil yang didapat setelah diterapkan tutor sebaya pada siklus I dapat dilihat skor yang diperoleh siswa FF sudah mulai meningkat, hal ini bisa dilihat pada grafik dibawah ini:

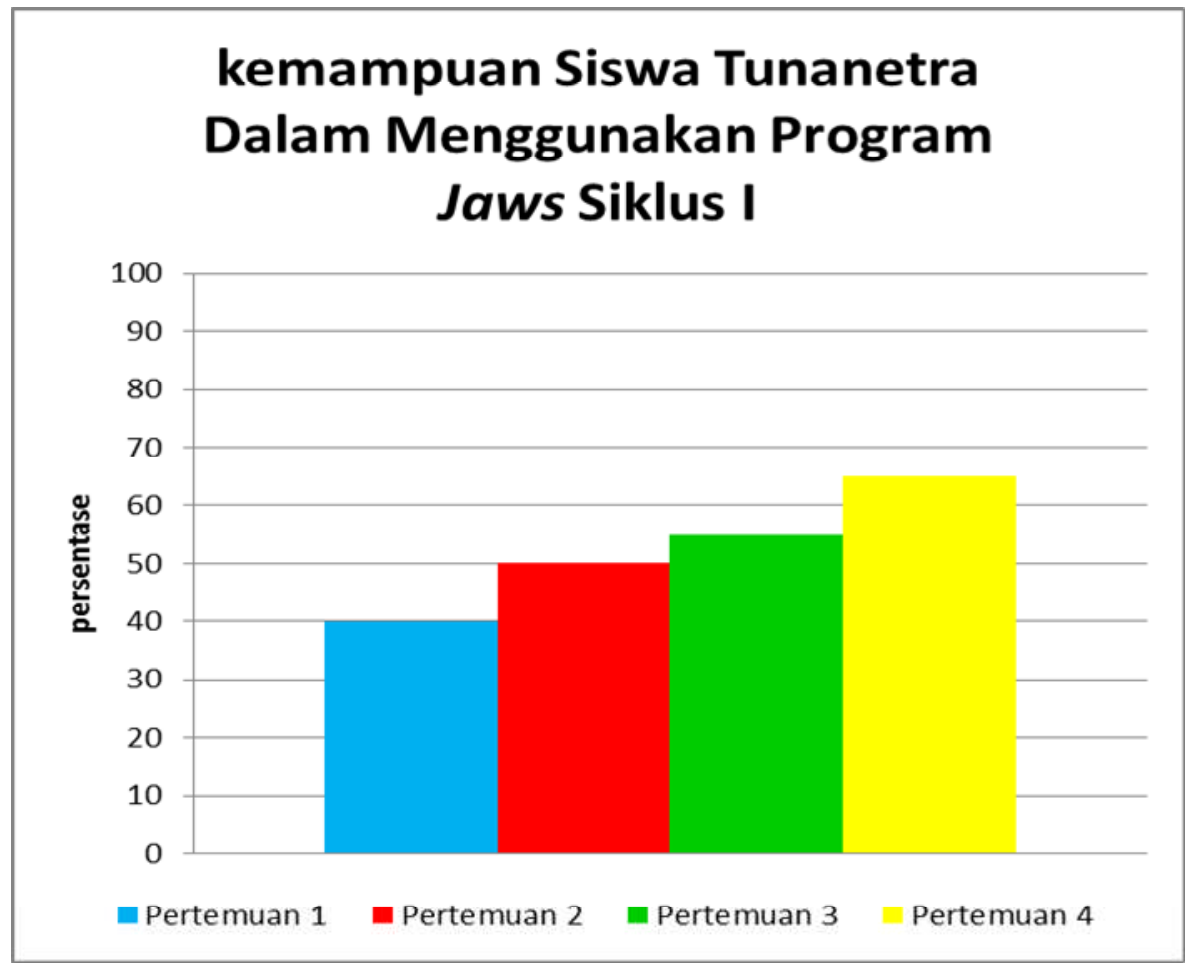

\section{Grafik 2. Rekapitulasi Nilai Kemampuan Menggunakan Program Jaws Pada Siklus I}

Berdasarkan grafik pada gambar diatas dapat terlihat adanya peningkatan pada siklus I. yang mana pada pertemuan pertama dari 20 aspek yang diamati anak hanya bisa 8 aspek diantaranya menebalkan huruf, memiringkan huruf, menggaris bawah huruf, mempraktekkan cara menggunakan jaws dalam membaca dokumen perhuruf, mempraktekkan cara menggunakan jaws dalam membaca dokumen perkalimat, menghapus tulisan, memindahkan baris baru, memberi spasi. sedangkan 12 aspek yang belum dikuasai anak diantaranya membuka lembar kerja baru, membuka file, menyimpan dokumen, membuka lembar kerja microsoft word, membuat tulisan ditengah, mengganti ukuran huruf, mengcopy tulisan, mempastekan tulisan, keluar dari lembar kerja microsoft word, mempraktekkan cara menggunakan jaws dalam membaca dokumen perkata, mempraktekkan cara menggunakan jaws dalam membaca dokumen perparagraf, memperbesar tulisan. Pada pertemuan pertama anak memperoleh nilai sebesar $40 \%$. 
Pertemuan kedua dari 20 aspek yang diamati siswa hanya menguasai 10 aspek diantaranya menebalkan huruf, memiringkan huruf, menggaris bawah huruf, mempraktekkan cara menggunakan jaws dalam membaca dokumen perhuruf, mempraktekkan cara menggunakan jaws dalam membaca dokumen perkalimat, menghapus tulisan, memindahkan baris baru, memberi spasi, memperbesar tulisan, membuat tulisan ditengah. Sedangkah 10 aspek lagi yang belum dikuasai anak adalah membuka lembar kerja baru, membuka file, menyimpan dokumen, membuka lembar kerja microsoft word, mengganti ukuran huruf, mengcopy tulisan, mempastekan tulisan, keluar dari lembar kerja microsoft word, mempraktekkan cara menggunakan jaws dalam membaca dokumen perkata, mempraktekkan cara menggunakan jaws dalam membaca dokumen perparagraf. Pertemuan kedua nilai yang diperoleh anak adalah sebesar $50 \%$.

Pertemuan ketiga dari 20 aspek yang diamati anak sudah mulai bisa 11 aspek diantaranya adalah menebalkan huruf, memiringkan huruf, menggaris bawah huruf, membuat tulisan ditengah, mengganti ukuran huruf, mempraktekkan cara menggunakan jaws dalam membaca dokumen perhuruf, mempraktekkan cara menggunakan jaws dalam membaca dokumen perkalimat, menghapus tulisan, memindahkan baris baru, memberi spasi, memperbesar tulisan. Sedangkan 9 aspek yang belum dikuasai adalah membuka lembar kerja baru, membuka file, menyimpan dokumen, membuka lembar kerja microsoft word, mengcopy tulisan, mempastekan tulisan, keluar dari lembar kerja microsoft word, mempraktekkan cara menggunakan jaws dalam membaca dokumen perkata, mempraktekkan cara menggunakan jaws dalam membaca dokumen perparagraf. nilai yang diperoleh pada pertemuan ketiga adalah $55 \%$.

Pertemuan keempat dari 20 aspek yang diamati anak sudah mulai bisa 13 aspek diantaranya menyimpan dokumen, membuka lembar kerja microsoft word, menebalkan huruf, memiringkan huruf, menggaris bawah huruf, membuat tulisan ditengah, mengganti ukuran huruf, mempraktekkan cara menggunakan jaws dalam membaca dokumen perhuruf, mempraktekkan cara menggunakan jaws dalam membaca dokumen perkalimat, menghapus tulisan, memindahkan baris baru, memberi spasi, memperbesar tulisan. sedangkan aspek yang belum dikuasai diantaranya membuka lembar kerja baru, membuka file, mengcopy tulisan, mempastekan tulisan, mempraktekkan cara menggunakan jaws dalam membaca dokumen perkata, mempraktekkan cara menggunakan jaws dalam membaca dokumen perparagraf, keluar dari lembar kerja microsoft word . pertemuan keempat anak memperoleh nilai $65 \%$.

Secara keseluruhan siswa FF memperoleh nilai pada pertemuan pertama sampai pertemuan keempat sebesar 40\%, 50\%, 55\%,dan 65\%. Berdasarkan data yang telah diperoleh dari empat pertemuan di atas dapat dilihat bahwa setelah diberikan tindakan melalui tutor sebaya kemampuan siswa mengalami peningkatan, meskipun nilai yang di dapatkan belum maksimal dan belum mencapai KKM pada peneliti dan kolaborator memutuskan untuk melanjutkan ke siklus II.

Hasil perolehan yang di dapat pada siklus II terlihat siswa mengalami peningkatan, hal ini bisa dilihat pada grafik berikut: 


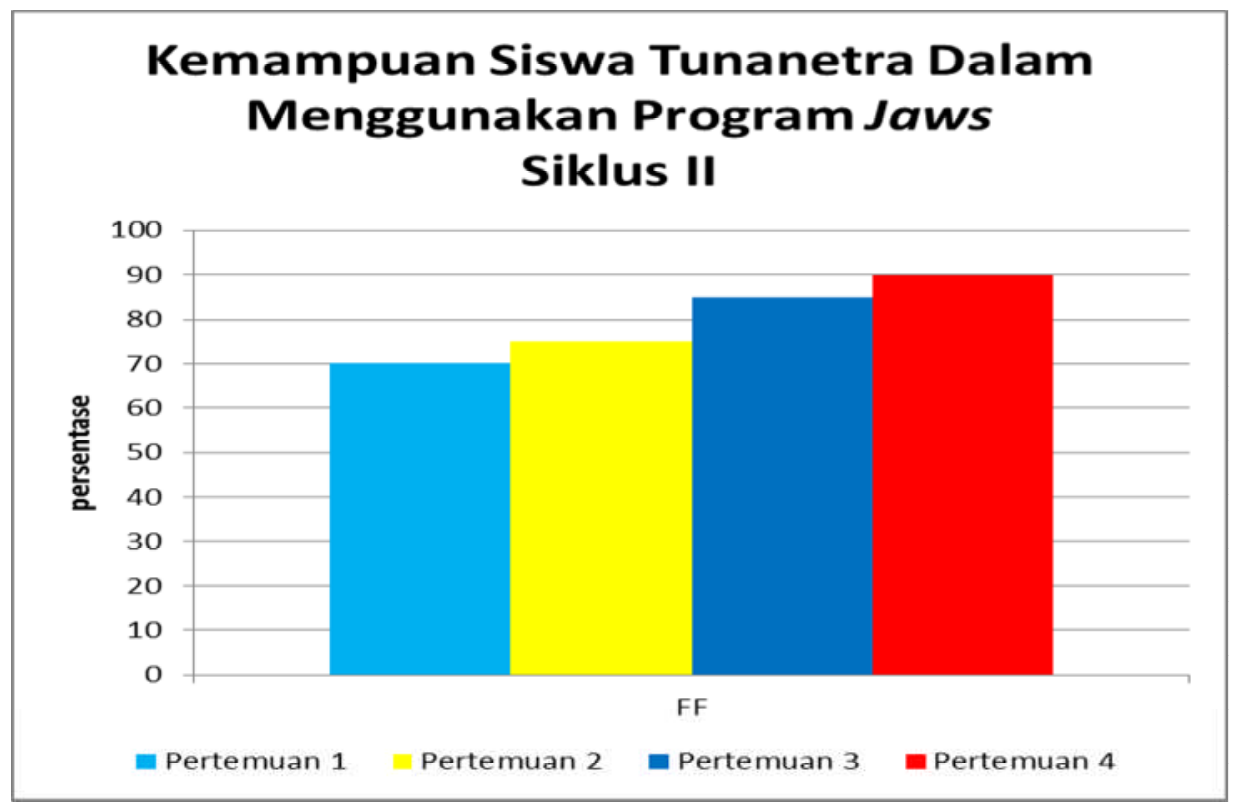

\section{Grafik 3. Rekapitulasi Nilai Kemampuan Menggunakan Program Jaws Pada Siklus II}

Berdasarkan hasil nilai yang telah diperoleh dari rekapitulasi data di atas dapat diketahui bahwa kemampuan siswa dalam menggunakan program jaws setelah diberikan perlakuan melalui tutor sebaya semakin meningkat. Pada pertemuan pertama siklus II dari 20 aspek yang diamati siswa mampu menguasai 14 aspek diantaranya menyimpan dokumen, membuka lembar kerja microsoft word, memiringkan huruf, menggaris bawah huruf, membuat tulisan ditengah, mengganti ukuran huruf, mempraktekkan cara menggunakan jaws dalam membaca dokumen perhuruf, mempraktekkan cara menggunakan jaws dalam membaca dokumen perkata, mempraktekkan cara menggunakan jaws dalam membaca dokumen perkalimat, menghapus tulisan, memindahkan baris baru, memberi spasi, memperbesar tulisan. Hasil yang diperoleh pada pertemuan pertama siklus II adalah sebesar 70\%.

Pertemuan kedua siklus II dari 20 aspek yang diamati siswa mampu menguasai 15 aspek diantaranya membuka lembar kerja baru, menyimpan dokumen, membuka lembar kerja microsoft word, menebalkan huruf, memiringkan huruf, menggaris bawah huruf, membuat tulisan ditengah, mengganti ukuran huruf, mempraktekkan cara menggunakan jaws dalam membaca dokumen perhuruf, mempraktekkan cara menggunakan jaws dalam membaca dokumen perkata, mempraktekkan cara menggunakan jaws dalam membaca dokumen perkalimat, menghapus tulisan, memindahkan baris baru, memberi spasi, memperbesar tulisan. sedangkan 5 aspek lagi yang belum dikuasai anak diantaranya membuka file, mengcopy tulisan, mempastekan tulisan, mempraktekkan cara menggunakan jaws dalam membaca dokumen perparagraf, keluar dari lembar kerja microsoft word. Pertemuan kedua hasil yang diperoleh adalah sebesar $75 \%$

Pertemuan ketiga siklus II dari 20 aspek yang diamati siswa mampu 17 aspek diantaranya membuka lembar kerja baru, membuka file, menyimpan dokumen, membuka lembar kerja microsoft word, menebalkan huruf, memiringkan huruf, menggaris bawah huruf, membuat tulisan ditengah, mengganti ukuran huruf, mengcopy tulisan, mempraktekkan cara menggunakan jaws dalam membaca dokumen perhuruf, mempraktekkan cara menggunakan jaws dalam membaca dokumen perkata, mempraktekkan cara menggunakan jaws dalam membaca dokumen perkalimat, menghapus tulisan, memindahkan baris baru, memberi spasi, memperbesar tulisan. Sedangkan 3 aspek yang belum dikuasai diantaranya mempastekan tulisan, keluar dari lembar kerja microsoft word, mempraktekkan 
cara menggunakan jaws dalam membaca dokumen perparagraf. pertemuan ketiga memperoleh hasil sebanyak $85 \%$.

Pertemuan keempat ketiga siklus II dari 20 aspek yang diamati siswa mampu sebanyak 18 aspek diantaranya membuka lembar kerja baru, membuka file, menyimpan dokumen, membuka lembar kerja microsoft word, menebalkan huruf, memiringkan huruf, menggaris bawah huruf, membuat tulisan ditengah, mengganti ukuran huruf, mengcopy tulisan, mempraktekkan cara menggunakan jaws dalam membaca dokumen perhuruf, mempraktekkan cara menggunakan jaws dalam membaca dokumen perkata, mempraktekkan cara menggunakan jaws dalam membaca dokumen perkalimat, mempraktekkan cara menggunakan jaws dalam membaca dokumen perparagraf, menghapus tulisan, memindahkan baris baru, memberi spasi, memperbesar tulisan. Hasil yang diperoleh pada pertemuan keempat siklus II adalah sebesar $90 \%$.

Keseluruhan siklus II siswa FF memperoleh nilai 70\%, 75\%, 85\%, dan 90\% Karena pada umumnya anak sudah mampu menggunakan shortcut dengan baik. Dari hasil yang diperoleh diatas dapat dilihat bahwa nilai siswa telah mengalami peningkatan yang cukup signifikan. Nilai yang paling tinggi dicapai oleh FF adalah sebesar 90\%. Siswa masih memerlukan bimbingan dan arahan tutor dalam menggunakan shortcut.

Berdasarkan data pada grafik di atas, dapat disimpulkan pada siklus I dan siklus II kemampuan anak sudah mulai meningkat dan siswa sudah bisa menguasai shortcut dalam menggunakan program jaws meskipun di beberapa aspek masih membutuhkan bantuan tutor. Karena pada umumnya siswa sudah bisa menggunakan program jaws. Maka peneliti bersama kolaborator memutuskan untuk menghentikan tindakan pada siklus II.

Pembelajaran dalam menggunakan laptop khususnya menggunakan program jaws, menuntut penguasaan dalam penggunaan shortcut jaws. Agar siswa dapat secara mandiri dapat menggunakan program jaws diperlukan adanya seorang pembantu yang bertindak sebagai pembimbing, petunjuk dijadikan sebagai tutor sebaya. Tutor sebaya dirasa tepat dalam pembelajaran menggunakan program jaws dikarnakan tutor dapat membantu siswa dalam membimbing, memberikan petunjuk, dan memberikan arahan dalam menggunakan shortcut jaws. Pada pelaksanan proses pembelajaran menggunakan program jaws. Menurut guru kelas sebagai kolaborator, peneliti sebagai guru praktisi telah melaksanakan pembelajaran dengan baik, peneliti menyampaikan pembelajaran sesuai dengan rencana pelaksanaan pembelajaran yang telah disusun bersama guru kelas.

Dari hasil penelitian dapat terlihat bahwa keterampilan menggunakan program jaws pada siswa tunanetra dapat ditingkatkan melalui penerapan tutor sebaya. Hal ini terlihat pada perolehan skor siklus I FF sebesar 40\%, 50\%, 55\%,dan 65\%. Dan pada siklus II sebesar 70\%, 75\%, 85\%, dan 90\%.

\section{Kesimpulan}

Berdasarkan hasil pembahasan penelitian yang telah dijelaskan dapat dilihat bahwa penggunaan tutor sebaya dapat meningkatkan keterampilan menggunakan program jaws pada siswa tunanetra. Proses pembelajaran penggunaan program jaws pada anak tunanetra kelas IX melalui tutor sebaya dapat dikatakan sesuai dengan langkah yang telah ditetapkan bersama kolaborator. Pelaksanaan penelitian ini dilakukan dalam 2 siklus, satu siklus terdiri atas 4 kali pertemuan. Dalam setiap pertemuan selalu peneliti awali dengan kegiatan awal, kegiatan inti dan kegiatan akhir.

Berdasarkan data yang telah diperoleh pada siklus I dan siklus II terlihat adanya peningkatan yang signifikan setelah diterapkan tutor sebaya dalam pembelajaran keterampilan menggunakan tutor sebaya. kemampuan penggunaan program jaws anak tunanetra kelas IX melalui tutor sebaya terlihat pada skor hasil belajar mengalami peningkatan.dari 65\% di siklus I menjadi 95\% di siklus II. Artinya anak menguasai keterampilan menggunakan program jaws. Sehingga disimpulkam bahwa pelaksanaan keterampilan menggunakan program jaws dapat ditingkatkan melalui tutor sebaya bagi anak tunanetra. 


\section{Daftar Rujukan}

Arjanggi, R. (2010). METODE PEMBELAJARAN TUTOR TEMAN SEBAYA MENINGKATKAN HASIL BELAJAR BERDASAR REGULASI-DIRI The Effectiveness of Peer Tutoring Method on Self-Regulated Learning Abstract, 14(2), 91-97.

Baharudin, E. (2006). PEMANFAATAN SOFTWARE UNTUK TUNANETRA DALAM Pendahuluan Tinjauan Teori, 4(2), 122-127.

Hadi, P. (2005). Kemandirian Tunanetra Orientasi Akademik dan Orientasi Sosial. Jakarta: Departemen Pendidikan Nasional.

Iskandar. (2011). Penelitian Tindakan Kelas. Jakarta: Gaung Persada Press.

Kunandar. (2016). Langkah-langkah Penelitian Tindakan Kelas. Jakarta: PT. Raja Grafindo Persada.

Muhadi. (2011). Penelitian Tindakan Kelas. Yogyakarta: Shira Media.

Rijalullah. (2003). Model Pembelajaran Tutorial Sebaya Pembelajaran BTQ. STAINU.

Safaruddin, M. Y., \& Efrina, E. (2013). PENGARUH PROGRAM JAWS TERHADAP KEMAMPUAN MENGETIK PADA TUNANETRA DI PSBN TUAH SAKATO PADANG. Jurnal Pendidikan Khusus, 2(3).

Suharmini, A., Suhardjono, \& Supardi. (2010). Penelitian Tindakan Kelas. Jakarta: Bumi Aksara.

Sumekar, G. (2009). Anak Berkebutuhan Khusus: Cara Membantu Mereka Agar Berhasil Dalam Pendidikan Inklusi. Padang: UNP Press.

Suyadi. (2015). Penelitian Tindakan Kelas dan Penelitian Tindakan Sekolah. Yogyakarta: Andi Offcet.

Yudhistira, D. (2013). Menulis Penelitian Tindakan Kelas Yang Apik. Jakarta: PT. Grasindo. 